\title{
VÉGTAGCSONK ÉS PROTÉZIS NYOMÁSELOSZLÁSÁNAK VIZSGÁLATA
}

\section{PRESSURE REPARTITION BETWEEN LOWER LIMB STUMP AND PROSTHESIS}

\author{
Forgó Zoltán ${ }^{1}$, Filep Róbert ${ }^{2}$, Tolvaly-Roșca Ferenc ${ }^{3}$ \\ ${ }^{1}$ Sapientia EMTE, Müszaki és Humántudományok Kar, Gépészmérnöki Tanszék, \\ Cím: 540485, Románia, Marosvásárhely / Koronka, 1C; \\ Telefon / Fax: +40-265-208172, levelezési cím: zforgo@ms.sapientia.ro \\ ${ }^{2}$ OrtoProfil Prod Romania Kft., Cím: 540485, Románia, Marosvásárhely, Hidvég \\ utca 44/A; Telefon / Fax: +40-265-264834, levelezési cím: rfilep@,ortoprofil.ro \\ ${ }^{3}$ Sapientia EMTE, Müszaki és Humántudományok Kar, Gépészmérnöki Tanszék, \\ Cím: 540485, Románia, Marosvásárhely / Koronka, 1C; \\ Telefon / Fax: +40-265-208172, levelezésicím:tferi@ms.sapientia.ro
}

\begin{abstract}
In case of accident or disease the limb amputation could be a lifesaving action performed by the physician. The consequence is a deteriorated life quality of the patient, but the use of limb prostheses can ameliorate this loss. A main factor by design and manufacturing of the prostheses is the comfort and it is influenced by several factors. Beside the anatomy of the limb stump, the materials used in the manufacturing of the prostheses are of major importance. Even more, the material used for welting the prosthesis has great impact regarding the comfortable use of it. This paper presents a measurement method for the recognition of dynamic load distribution between the limb stump and prosthesis, through which the quantitative evaluation of the welt materials can be done.
\end{abstract}

Keywords: prosthetic limb, prosthesis, pressure repartition

\section{Összefoglalás}

Balesetek vagy betegségek következtében számos esetben életmentő beavatkozásként az orvosok végtag-amputációt végeznek, mely gyökeresen megváltoztathatja pácienseik addigi életminőségét. A régi tevékenységeknek az újra felvételét segítik a különböző protetizálási eljárások, melyek következtében a páciens végtagprotézist kap. Ezek gyártásánál igen fontos tényező a protézis kényelmessége, mely több anatómiai és müszaki jellemzőtől függ. A végtagcsonk anatómiáján kívül a protézis megépítésére használt anyagok is hozzájárulnak ehhez, és itt ki kell emelni a protézis bélelésére használt anyag fontosságát, hiszen ezen keresztül kerül kontaktusba a végtagcsonk a kemény anyagú protézissel. Jelen dolgozatban egy olyan eljárást mutatunk be, mely segítségével fel lehet térképezni az érintkezésben levő felületek közötti nyomás dinamikus alakulását, lehetővé téve a különböző bélelési anyagok kvantitatív jellemzését.

Kulcsszavak: müvégtag, protézis, nyomáseloszlás 


\section{Bevezető}

Egy végtag elvesztése meghatározó lehet egy ember életében. Az illető személy életvitele megtörik, és az akaraterő fontos tényező lesz az életminőség javításának hosszas folyamatában.

Természetesen a müvégtagok alkalmazásától sem lehet eltekinteni. A páciens felépülésére fordítható összeg határozza meg ezen alkalmazandó müvégtagok milyenségét. Napjainkban a modern technológiák segítségével, olyan művégtagok készülnek, melyek funkcionalitásban hasonlítanak az elvesztett végtaghoz (1. ábra), viszont bonyolult felépítésük nem teszi elérhetővé minden rászoruló számára. Az alsóbb árkategóriába tartozó protézisek leginkább a külalak „élethüségével” próbálják enyhíteni a páciensek mindennapjait (2. ábra).

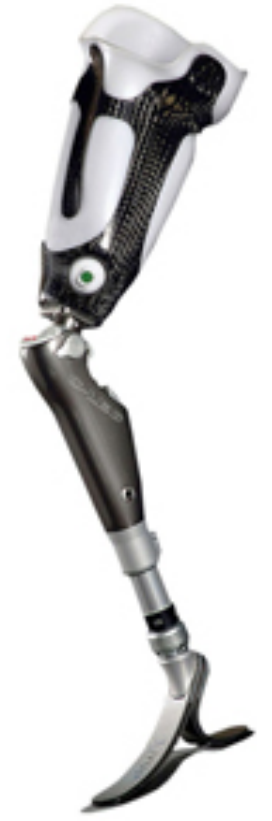

1. ábra. Az OttoBock cég által gyártott C-Leg lábprotézis, mely mikroprocesszor által vezérelt mozgásban alkalmazkodik a páciens tevékenységéhez [1]

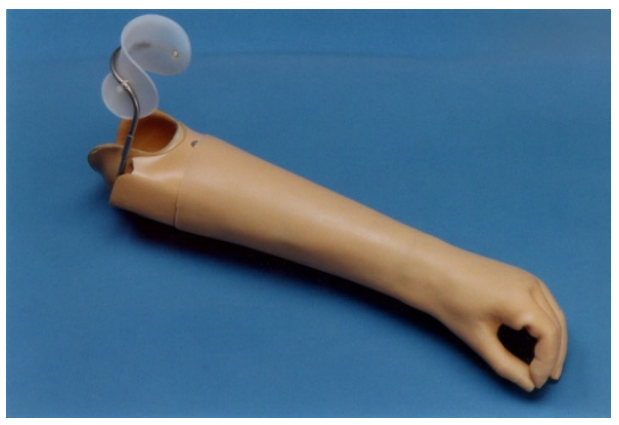

a)



b)

2. ábra. a) Passziv müvégtag, mely mechanikai vezérléssel mozgatható hüvelykujjat tartalmaz.

(www.swisswuff.ch/tech/?p=428)

b) elemi funkcionalitással rendelkezö protézis, melyet az idegpályák segitségével, elektródákon keresztül lehet vezérelni.

(www.bostonmagazine.com/health/arti cle/2013/11/26/prosthetics-researchboston-arm/)

Mindezek mellett, kiemelt figyelmet kell fordítani annak a felületnek a kialakítására, amely érintkezésbe kerül a végtagcsonkkal. A lágyszövetek károsodásának kockázata legföképpen a lábprotézis esetén nagynak mondható, mivel a páciens a teljes súlyával terheli az említett felületet. Olyan nyomáseloszlásról beszélhetünk, mely időben változó, ciklikus, és teljes mértékben függ a mozgás dinamikájától. A protézis gyártásának technológiája figyelembe veszi a végtagcsonk alakját, formáját, és ennek megfelelően alakítják ki a tokot, melybe 
behelyezi a végtagcsonkot a páciens a müvégtag viselésekor. A kényelem biztosítása érdekében a kemény felület egy puha anyaggal van kibélelve, viszont a végtagcsonk formája, lágy és kemény szövetek jelenléte, a páciens fájdalomküszöbe, mind olyan tényező, mely egyedivé tesz minden müvégtagot. Ezek mellett a páciens egészségi állapota (pl. cukorbetegség) is nagy hatással van a protézis elkészítésekor használt bélésanyagok használatára.

\section{A berendezés és a mérés módszer- tanának bemutatása}

A jelenleg is folyó kutatás végcélja egy olyan mérési rendszer kidolgozása és megvalósítása, melynek segítségével feltérképezhető egy végtagcsonk és a rá helyezett művégtag közötti dinamikus nyomáseloszlás. Ennek segítségével nemcsak a kényelem szubjektív megítélése zárható ki, hanem nyomon követhető az időben változó végtagcsonk terhelése is. Abban az esetben, ha ez „veszélyesen” megnő, akkor természetesen egy új tok gyártása javasolt.

E dolgozat elkészültéig sikerült a mérés és kiértékelés módszertanát kidolgozni. A két felület közötti nyomást hat nyomásérzékelö bélyeg (3. ábra) segítségével rögzítettük egy adatgyüjtő berendezésen keresztül, majd a kapott értékeket görbékként jelenítettük meg.



(a)

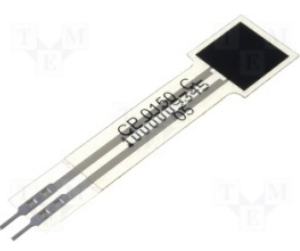

(b)
3. ábra. A használt $C Z N-C P 6$ (a) és $C Z N-C P 9$ (b) nyomásérzékelö bélyegek

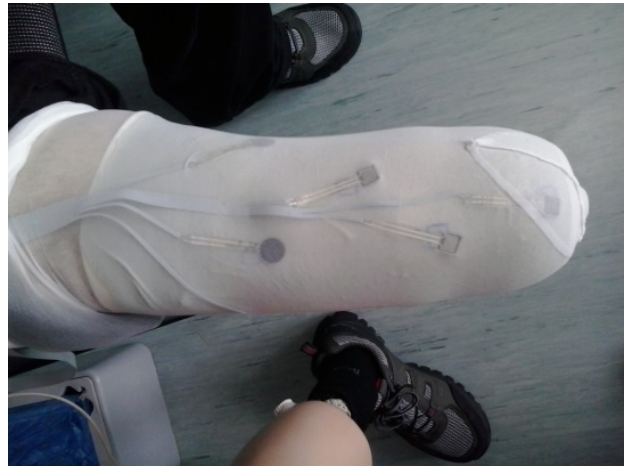

4. ábra. A hat érzékelö helye a végtagcsonkon (az ábrán ötnek a helyzete létható, míg a hatodik hátul helyezkedik el)

Az első válaszra váró kérdés az érzékelök elhelyezését érintette. Mivel kezdetben ideiglenes mérőberendezésről beszélhetünk, egyértelmü volt a bélyegek elhelyezése a végtagcsonk és a bélés, nem pedig a bélés és a müanyagtok között. Amint a 4. ábrán is látható, a végtagcsonkra egy zokni van húzva, majd ezen helyezkednek el az érzékelők. Azért, hogy ne mozduljanak el mérés közben, egy harisnya segítségével lettek rögzítve. A bélyegek helyzete a végtagcsonkon az eddigi orvosi tapasztalat eredményeként volt megállapítva. A begyüjtött jelek LabJack UE9 adatgyüjtőn keresztül jutottak a számítógépbe, ahol lehetséges volt ezek kiértékelése.

\section{Kísérleti eredmények bemutatása}

A méréseket több élethelyzetben is elvégeztük, illetve kiértékeltük:

- a páciens sétálása közben (5.a ábra);

- a páciens álló helyzetében, mikor mind a két lábán áll (5.b ábra);

- a páciens álló helyzetében, mikor a sérült lábán áll (5.c ábra);

- a páciens álló helyzetében, amikor az egészséges lábán áll (5.d ábra);

- a páciens a súlypontját változtatja az egészséges és sérült lábára támaszkova (5.e ábra). 


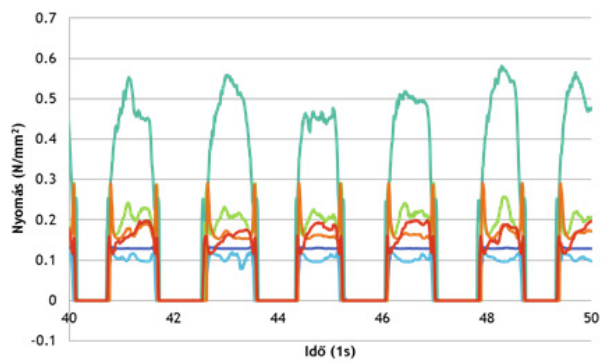

(a)



(b)

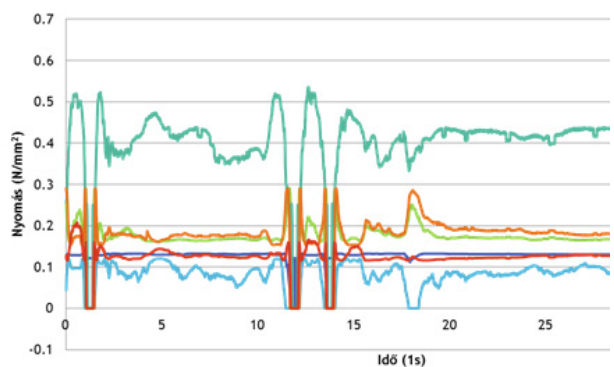

(c)

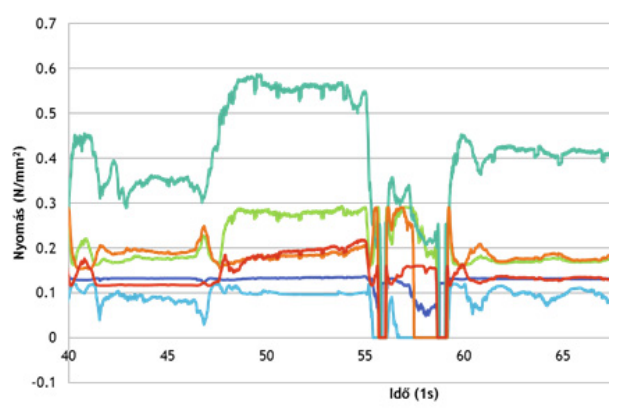

(d)

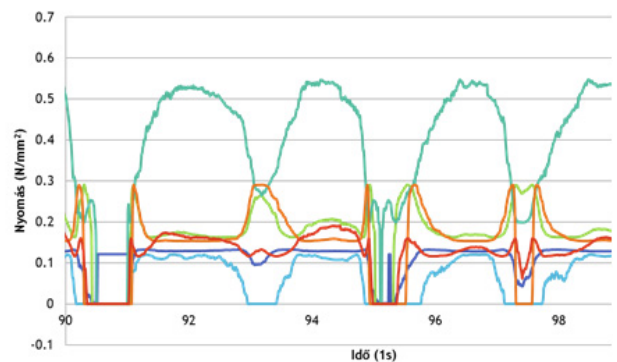

(e)

5. ábra. A kiértékelt nyomásgörbék a különböző kisérletek során



6. ábra. A sétálási kisérlet: az adatgyüjtő a páciens derekára van erösitve.

A feldolgozott adatok egyértelmüvé tették, hogy a kidolgozott és bemutatott módszer lehetőséget nyújt a végtagcsonk és a protézis közötti nyomás feltérképezéséhez. Továbbá rugalmas alkalmazást is biztosít, mivel az amputációk esetenként különböznek, így a kialakult végtagcsonkhoz az alkalmazkodás elengedhetetlen.

\section{Szakirodalmi hivatkozás}

[1] Máyer Á. A.: Amputáltak testtudata és állásbiztonsága. Doktori értekezés, Semmelweis Egyetem, Budapest, 2011. 